\title{
THE STRUCTURE OF A TESTIS FROM A CASE OF HUMAN HERMAPHRODITISM
}

\author{
R. H. WHITEHEAD \\ Anatomical Laboratory, University of Virginia \\ FIVE FIGURES
}

The testis which I am about to describe was obtained through the kindness of Dr. E. M. Prince, of Birmingham, Alabama. A report of the case was recently made by Dr. Prince, ${ }^{1}$ from which I extract the following history:

The patient, apparently a girl, eighteen years of age, consulted Dr. Prince stating that she had never menstruated, and that she suffered from headaches supposed to be due to that fact; she had withdrawn from the college she had been attending because of the headaches, which were worse about every twenty-eight days. She appeared to be a healthy, robust girl, refined and intelligent. There was a heavy growth of hair upon the head; the voice was soft and feminine, and the breasts well developed, rather larger than ordinarily seen in a girl of her age. The hips were typically feminine; the mons veneris was rather scantily covered with hair, the labia majora were normal; the clitoris was not enlarged; and the hymen was unruptured. No uterus could be made out by rectal examination. The vagina was about 2 inches long; and terminated in a blind pouch. In the upper part of each labium majus a body could be felt which was freely movable. The diagnosis made was congenital absence of the uterus with hernia of both ovaries. At the operation (exploratory laparotomy) a small body the size of a pecan was found at the usual site of the uterus; and to the left of this there was found an apparently normal ovary with a rudimentary tube. At a subsequent operation the two bodies in the labia majora were removed, and were found to be testes, a diagnosis which was afterwards confirmed by a pathologist.

In a letter Dr. Prince informs me that his patient made an uneventful recovery from the operations; furthermore, that she has the normal liking of a young woman for the society of young

1 E. M. Prince, A case of true hermaphroditism. Jour. Amer. Med. Ass., vol. 58, no. $17,1912$. 
men, and is even contemplating matrimony. So that, if the surgeon's diagnosis of an ovary in the pelvis can be accepted, this was a case of true anatomical hermaphroditism; and moreover, in spite of the presence of two extra-abdominal testes, the secondary sex characters of the individual were clearly those of the female.

In response to my request for some material from this interesting case, Dr. Prince very courteously sent me one of the testes; the other one had been misplaced and could not be found. The gland was received fixed in formalin, and appeared quite normal. The location of the digital fossa of the epididymis showed that it was from the right side of the body. It measured $4.5 \times 2 \times 1.5$ $\mathrm{cm}$., and was acordingly somewhat smaller than the average adult testis. On microscopic examination of sections of the testis (fig. 1) it is seen that the seminiferous tubules are abnormally small. The diameters of a large number measured varied from 0.08 to $0.12 \mathrm{~mm}$., and none were found whose diameter was as great as $0.15 \mathrm{~mm}$. The walls of the tubules are considerably thickened, the thickening being due to hyaline material devoid of nuclei and situated between the tubule-wall proper and the epithelial cells. The lumina of the tubules are filled with cells, the vast majority of which are unquestionably Sertoli cells. Their granular processes freely anastomose with one another forming a syncytium which fills the tubule. Here and there, however, cells may be seen which have some features suggestive of spermatocytes. They consist of a nucleus surrounded by a scanty amount of cytoplasm, the whole lying within a clear area between two Sertoli cells; two such cells are shown in the central tubule in figure 1. The fact, however, that their nuclei are quite small, contain very little chromatin, and, indeed, do not differ from the nuclei of undoubted Sertoli cells, makes it impossible to feel certain as to their nature. Extensive search revealed a very few cells which seemed clearly to be spermatocytes (fig. 2). Such cells have large nuclei fairly rich in chromatin, and occupy clear areas between the Sertoli cells. No spermatids and no spermatozoa could be found, nor were any mitotic figures observed anywhere. Accordingly it is certain that the testis was not functionating so far as the formation of germs cells is concerned. 
The interstitial cells are much more numerous than in the normal testis (fig. 1) and appear quite normal. They contain granules which in paraffin sections stain readily with iron-haematoxylin; in frozen sections these granules have a greenish brown tinge, and stain with Sudan III. The connective tissue fibers among the cells do not appear unduly numerous. Thus the structure of this testis is the same as that found in many ectopic testesa structure which is not only compatible with, but which, according to one hypothesis, is accountable for, the male secondary sex characters of cryptorchids. The body and tail of the epididymis are small, but the head is somewhat enlarged owing to the presence of a firm nodule imbedded in its lateral surface, the structure of which will be described later. In sections of the body of the epididymis the cross sections of the ductus are abnormally small, and the connective tissue between them is thickened. The epithelial cells of the ductus are low and cuboidal, typical columnar cells are entirely absent, and very few cilia can be seen. A ductus deferens could not be located in connection with the epididymis, nor could it be seen in sections through the tail of that structure.

The nodule mentioned above as imbedded in the lateral surface of the head of the epididymis mẹasured $1 \times 0.5 \times 0.5 \mathrm{~cm}$. On section it was not encapsulated nor separated in any distinct way from the surrounding tissues of the epididymis. Superficially it was continuous with the connective tissue of the tunica vaginalis, while its deep surface passed into the stroma of the caput. Microscopic examination revealed the following structure: Beneath the tunica vaginalis are several layers of rather dense connective tissue and beneath this, masses of cells of epithelioid type arranged in various ways. I have attempted to show the more common modes of arrangement in figures 3,4 and 5 . In the first case (fig. 3) one sees small, more or less oval groups of cells surrounded by thick walls of densely laminated connective tissue; the cell-boundaries are quite indistinct, and the appearance suggests cross-sections of tubules with sclerotic walls. In other instances (fig. 4) the collections of cells are much larger, the cytoplasm stains feebly, while the cell-boundaries are very clearly 
brought out. Such collections are surrounded by a thin capsule of connective tissue, from which septa pass in to subdivide the collection into smaller groups. Again.(fig. 5) the picture presented is that of a section of a ball of cells situated on the end of a stalk of connective tissue, fibers from which surround the mass of cells and also penetrate it. Deeper in beneath the region of the cells the stroma becomes much more cellular, and contains smooth muscle as well as spindle shaped connective tissue cells; its deep surface shades off into the stroma of the caput epididymidis. Everywhere in the nodule there is an astonishing number of blood vessels, whose middle coats especially are much thickened in many instances. It was rather expected that this nodule would prove to be a rudimentary ovary; but I must confess my inability to make the diagnosis and must leave the question of its nature open. Theoretically, it may be a rudimentary sclerotic ovary, a sclerotic adrenal 'rest,' or a vestige of the Wolffian body; and something might be said in favor of each of these views. The fact that it was incorporated in the caput epididymidis and that its connective tissue was directly continuous with that of the epididymis inclines me to regard it as a vestige of the Wolffian body, though, as stated above, I am not able to come to any positive conclusion. in the matter.

The prominent features of this case are furnished by the coexistence in the same individual of two ectopic testes with a probable ovary, typical external female genitals, and typical female secondary sex characters. Anatomists are, quite justly, suspicious of cases reported as true hermaphroditism. Doubtless true physiological hermaphroditism in man is unknown. On the other hand, it is certain that male and female sex-glands, one or both being in a more or less rudimentary condition, have been found in the same person; so that in an anatomical sense true hermaphroditism does occur. The exhaustive monograph of $\mathrm{v}$. Neugebauer $^{2}$ contains the records of five cases, at least two of which (those of Garre and v. Salén) are undoubtedly examples of this condition. In both of these cases, however, the two glands

${ }^{2}$ v. Neugebauer, Hermaphroditismus beim Menschen. Leipzig, 1908. 
were combined in one organ constituting a so-called ovo-testis. To these Gudernatsch ${ }^{3}$ has recently added a third. The proper classification of the case reported here must remain uncertain so long as it is impossible to make a microscopical examination of the supposed ovary. It is, indeed, improbable that a surgeon of experience in pelvic operations would be mistaken as to a normal ovary; but the mistake has been made a number of times, and the microscopical examination is necessary in every case.

My primary interest in this case was due to a desire to investigate its bearing upon the theory that attributes the development of male secondary sex characters to an internal secretion of the interstitial cells of the testis. It is obvious that the evidence derived from it is strongly opposed to that theory; for in spite of the existence of an abnormally large amount of interstitial cells, the secondary sex characters were typically female.

The case accentuates the fact that the evidence presented by these abnormal or pathological cases is quite contradictory in its character. Thus, it is by no means rare in pseudohermaphrodites with female sex characters to find ectopic testes which have the same structure as the testes found in ordinary cryptorchids with typical male sex characters. From the study of such cases alone one would very naturally conclude that the interstitial cells are in no way concerned with the development of the secondary sex characters of the male. On the other hand, the theory mentioned above was based by Ancel and Bouin ${ }^{4}$ for the most part upon a study of cryptorchid horses and pigs. ${ }^{5}$ It seems clear that the question cannot be settled by the study of such evidence. Some method of experimentation must be devised by means of which all the cells of the seminal tubules may be destroyed, leaving the interstitial cells to go on to full development.

\footnotetext{
${ }^{3}$ Gudernatsch, Hermaphroditismus verus in man. Amer. Jour. Anat., vol. 11, 1911.

4 Ancel et Bouin, Recherches sur la rôle de la glande interstitielle du testicule. Jour. Physiolog. et Path., t. 6, 1904.

${ }^{5}$ For a marked example, see a paper by the writer: A peculiar case of cryptorchism. Anat. Rec., vol. 2, 1908.
} 
R. H. WHITEHEAD

Fig. $1 t$, seminiferous tubule; $h$, hyaline portion of tubule wall; $i c$, interstitial cells; iron-haematoxylin stain. $\times 400$.

Fig. $2 s c$, Sertoli cells; $s p$, spermatocyte; haematoxylin and Congo red stain. $\times 1000$ 

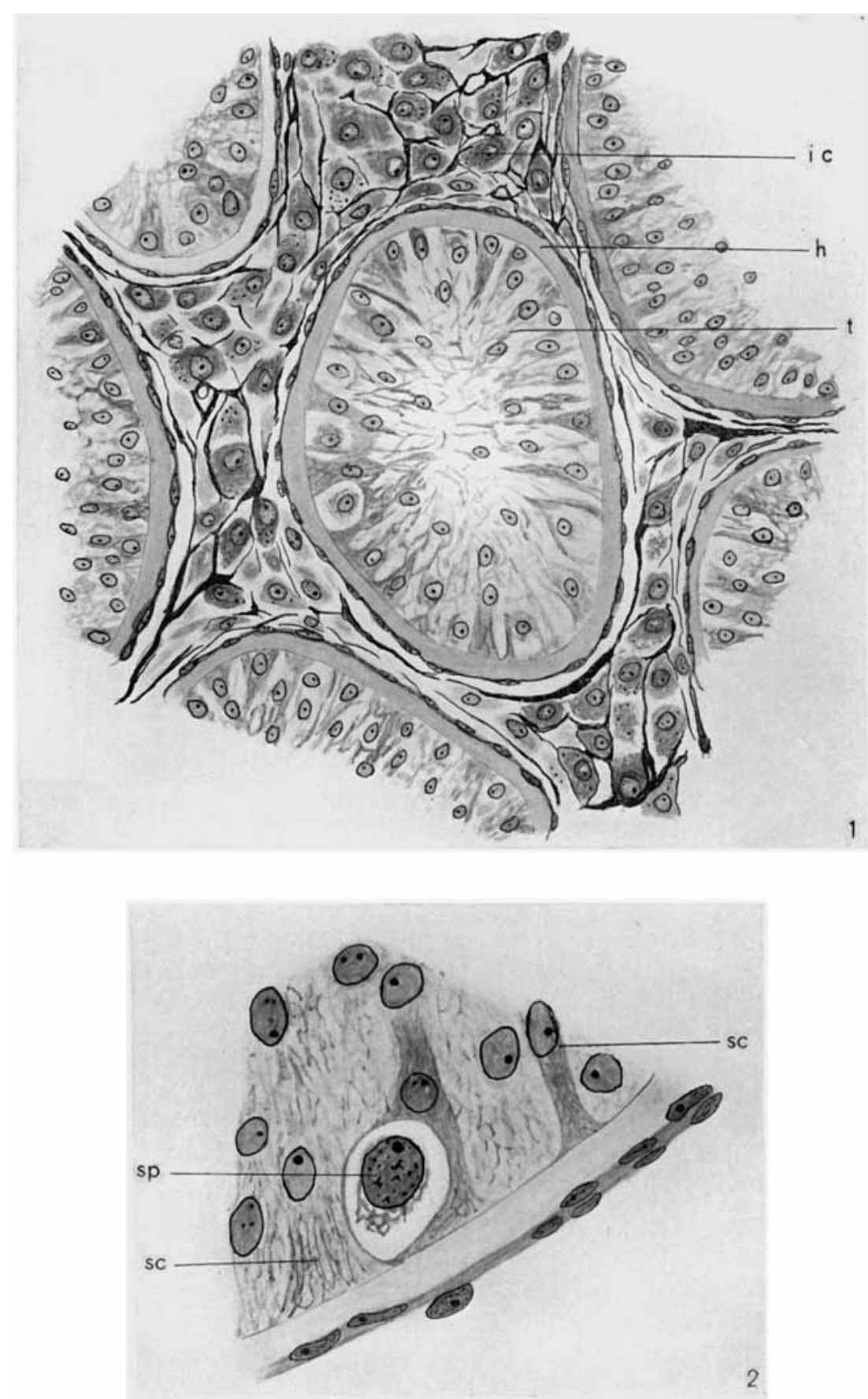

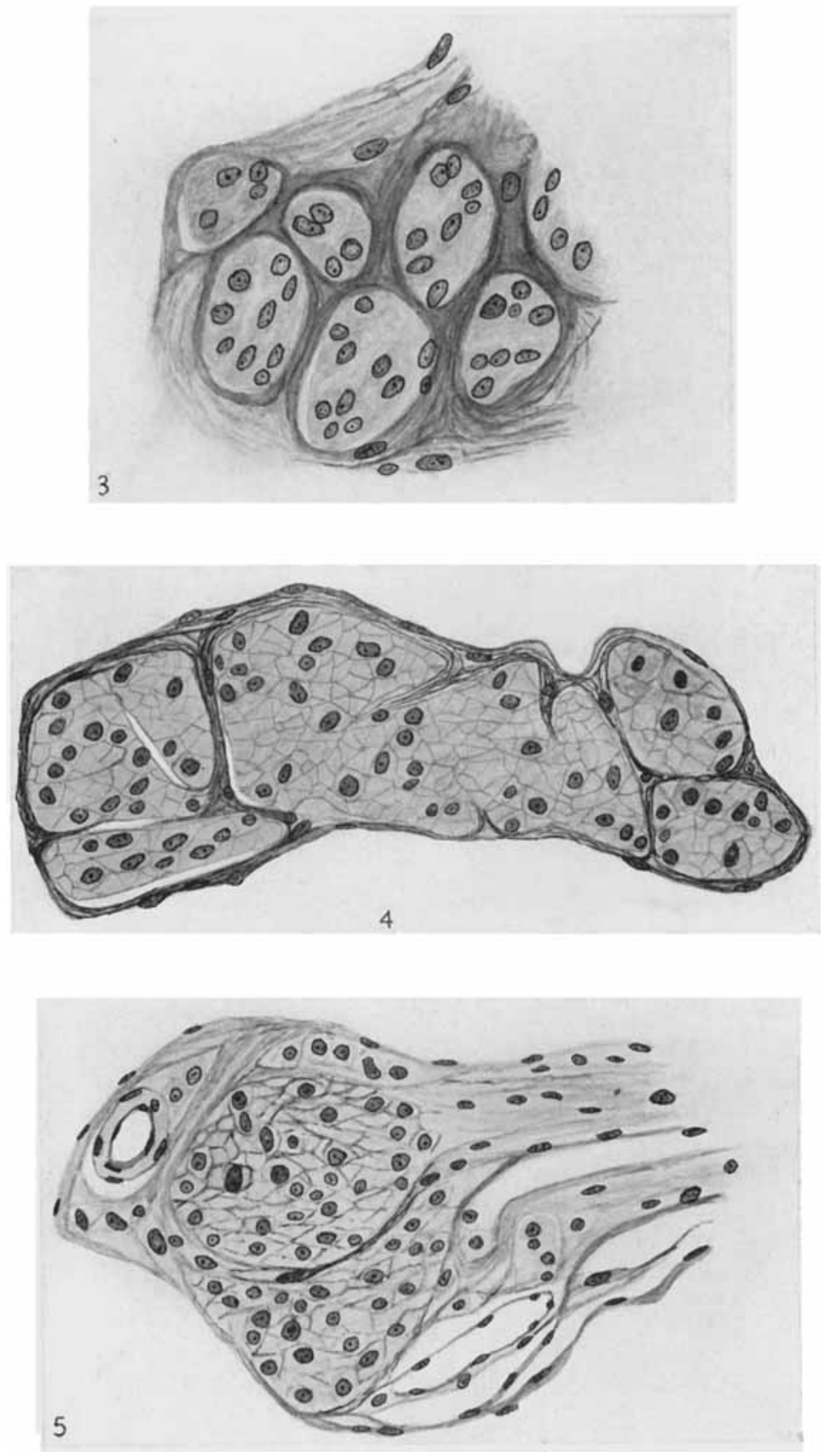

Figs. 3, 4, 5 Figures to illustrate the modes of arrangement of the cells in the nodule of the caput epididymidis; figure $3, \times 500$; figures 4 and $5, \times 400$. 